
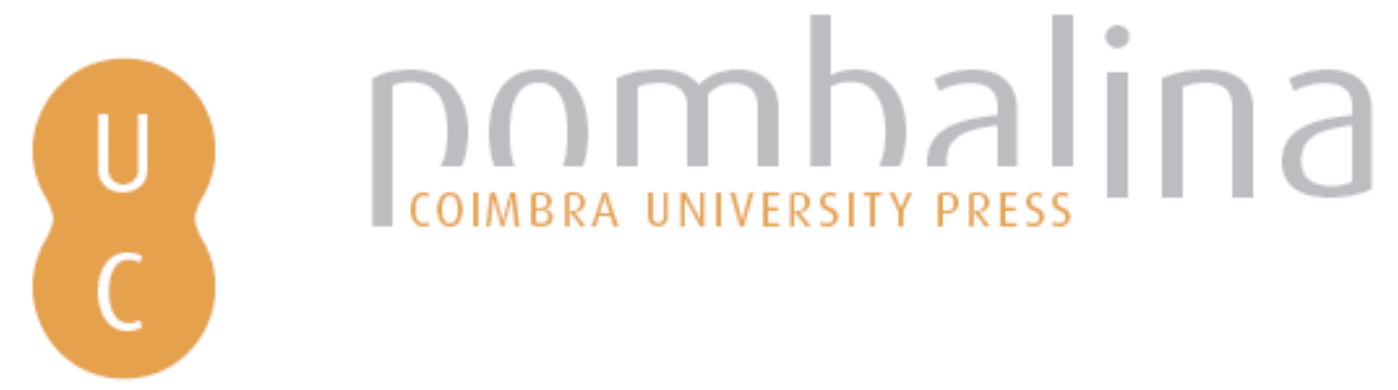

\title{
Promoting active aging inside portuguese residential institucions for the elderly: is there something missing?
} \author{
$\begin{array}{ll}\text { Autor(es): } & \text { Vieira, Cristina C.; Oliveira, Albertina L.; Lima, Margarida P.; Ferreira, } \\ \text { Sónia M. }\end{array}$
}

Publicado por: Imprensa da Universidade de Coimbra

URL persistente:

URI:http://hdl.handle.net/10316.2/32552

DOI:

DOI:http://dx.doi.org/10.14195/978-989-26-0732-0_22

Accessed : $\quad$ 26-Apr-2023 10:35:22

A navegação consulta e descarregamento dos títulos inseridos nas Bibliotecas Digitais UC Digitalis, UC Pombalina e UC Impactum, pressupõem a aceitação plena e sem reservas dos Termos e Condições de Uso destas Bibliotecas Digitais, disponíveis em https://digitalis.uc.pt/pt-pt/termos.

Conforme exposto nos referidos Termos e Condições de Uso, o descarregamento de títulos de acesso restrito requer uma licença válida de autorização devendo o utilizador aceder ao(s) documento(s) a partir de um endereço de IP da instituição detentora da supramencionada licença.

Ao utilizador é apenas permitido o descarregamento para uso pessoal, pelo que o emprego do(s) título(s) descarregado(s) para outro fim, designadamente comercial, carece de autorização do respetivo autor ou editor da obra.

Na medida em que todas as obras da UC Digitalis se encontram protegidas pelo Código do Direito de Autor e Direitos Conexos e demais legislação aplicável, toda a cópia, parcial ou total, deste documento, nos casos em que é legalmente admitida, deverá conter ou fazer-se acompanhar por este aviso.

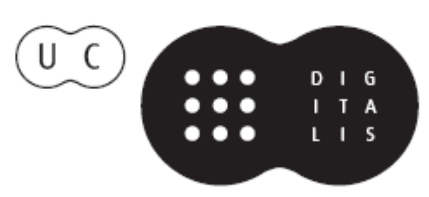


MPRENSA DA

UNIVERSIDADE

DE COIMBRA

COIMBRA

UNIVERSITY

- PRESS 


\title{
PROMOTING ACTIVE AGING INSIDE PORTUGUESE RESIDENTIAL INSTITUTIONS FOR THE ELDERLY: IS THERE SOMETHING MISSING?
}

\author{
Cristina C. Vieira, Albertina L. Oliveira, Margarida P. Lima, Sónia M. Ferreira ${ }^{52}$
}

\begin{abstract}
The definition of active aging endorsed by the World Health Organization (WHO) in 2002 requires from different professionals and institutions a systematic work with people along the process of ageing, involving the promotion of health, the assurance of conditions of security and the offering of opportunities for participation, including learning activities that promote personal development and well-being. Seniors living in residential care homes are not excluded from this definition and it is important to know how these institutions are trying to respond to the challenge launched by the WHO about a decade ago. This chapter is based on an empirical study carried out in eight residential homes for the elderly in the municipality of Coimbra, Portugal, and involved a sample of 146 old people who answered a structured interview protocol. The main objective of this research was to elicit elders' perceptions about their life in institutions, in order to outline possible changes with the goal of promoting their quality of life in the last years of their life in a context different from their family or their own homes. The focus of our analyses in this chapter is on the elders' answers about their participation in learning and recreational activities promoted by institutions where they live and also about their self-perceptions about their abilities to learn and to contribute to a dynamic environment inside the institution that goes beyond the 'assistentialist' perspective of these entities. Despite the small size of the sample, data showed that there is a long way to go in order to effectively
\end{abstract}

\footnotetext{
52 Faculty of Psychology and Sciences of Education, University of Coimbra, Portugal.

Email of the first author: vieira@fpce.uc.pt.
} 
offer opportunities for participation to institutionalized elders, whether it involves experiences of learning and of personal development, or ordinary decisions related to their daily life as individuals and full citizens.

Keywords: Active aging; Institutionalization; Elders' perceptions; Participation in learning activities.

\section{Introduction}

The active aging approach established by the World Health Organization (WHO) in 2002 recognizes the importance of the rights of older people and the principles of independence, autonomy, health, safety and continuous participation of people, along the aging process, in social, economic, learning, cultural, spiritual and civic issues, and not only their ability to be physically active or to have good health. Active aging is therefore intended to promote a new image of old age and is anchored in ideas of emancipation, citizenship and participation (Almeida, 2013). Participation in a broader sense means more than possible economic contributions of older people to society (productive aging), but also includes the performance of activities with the goal of developing their self-esteem, like volunteer activities in the community, and the full utilization of their capacities, with learning programs and recreational activities.

It is a well-known fact that being old is not synonymous with being intellectually unable to conduct a normal life or to be incapable of learning, when we are talking about an aging process without psychopathology (Simões, 1990; 1991; 2006). The participation of the elderly in activities that foster their sense of belonging to a community and their involvement as active citizens has been positively correlated with their quality of life when such activities are significant to them as individuals (Kelly, 1996; Oliveira et al., 2011; Phellas, 2013) and when the things they do have some continuity with their past positive experiences (Baltes \& Baltes, 1990).

Considering the longevity of the population, we now can have people who may live more than two and a half decades after retirement with 
health conditions good enough to maintain their intellectual capacities, mnemonic skills and learning abilities (Simões, 1999). The optimization of knowledge, abilities and competencies in old age is a request for the person to get older successfully in an active way and a highly preferable means of mitigating the effects of aging (Martins, 2010; Jacob \& Fernandes, 2011). Concerning elders' participation in learning and recreational opportunities, Knowles (1990) outlined that the willingness to learn in adults (regardless of age) is greater when they understand its usefulness and the learning is related to real situations of their daily lives; also, the immensity of their experiences is a rich resource for their learning and the strategies that take advantage of this diversity of individual differences will be more effective in calling them to participation.

These preoccupations with old people's participation and the positive effects in their aging process of the activities they do of their own free will are not new matters in political agendas for the elderly. Many years ago, in 1976, one of the main recommendations of UNESCO General Conference about Adult Learning, held in Nairobi, declared that the conservation of the physical and intellectual faculties of the elderly was crucial, along with the continuation of their participation in public life and their access to knowledge domains or types of activities which were out of reach throughout their life (Simões, 2002). Almost three decades later, among the central themes running through the Madrid International Plan of Action on Ageing, 2002, it is possible to find the following proposal to foster a better aging process for all:

"Provision of opportunities for individual development, self-fulfilment and well-being throughout life as well as in late life through, for example, access to lifelong learning and participation in the community while recognizing that older persons are not one homogenous group" (MIIPPA, 2002, pp. 17-18) ${ }^{53}$.

53 Available in http://undesadspd.org/Ageing/Resources/MadridInternationalPlanofActiononAgeing.aspx (accessed September, 26, 2013). 
In line with these previous political intentions we can find the five operating axes that were the core of actions of the European Year of Active Aging and Solidarity between Generations, 2012, in Portugal (AEEASG, 2012) ${ }^{54}$ :

- Employment, Work and Lifelong Learning: along the aging process people should have the right to work and to learn whenever they want and as long they want, regardless of age.

- Health, Welfare and Living Conditions: along the aging process people should have the right to feel healthy and safe, meet their basic needs, have fun, and, if necessary, to receive care.

- Intergenerational Solidarity and Dialogue: along the aging process people should have the right to participate in a society for all ages, contributing to it with their different talents and backgrounds in interaction with others.

- Volunteering and Civic Participation: along the aging process people should have the right to be a part of the community and to be involved in it to contribute to a better community.

- Knowledge and Social Awareness: along the aging process people should have the right to have access to knowledge in order to act better and to be helped to become more conscientious.

Seniors living in residential care homes should not be excluded from these recommendations for the promotion of an active aging. This can be done by fostering participation among older ages and it is known that one of the implications of population ageing is the increasing number of the elders living nowadays in residential care institutions.

The process of institutionalization is a complex one and its impact on the individual depends on several factors, including personal and environmental. According to Lima (2010), the decision to go to live in an institution could be seen by the old person as a good opportunity to ensure his/her quality of life in later stages, but it should imply his/her

54 Available in http://www.igfse.pt/upload/docs/2012/Programa\%20A\%C3\%A7ao AnoEuropeu2012.pdf (accessed October, 12, 2013). 
participation in minor or large decisions, always requiring from the person the stimulation and the use of his/her cognitive abilities, the respect for his/her life experience and his/her freedom of choice.

Among the main characteristics of a good quality of life in residential institutions for the elderly, Kane (2003) outlined eleven: autonomy, dignity, privacy, individuality, security, physical comfort, interpersonal relationships, significant activities, functional competence, enjoyment and spiritual well-being. All these aspects are present in the challenge of the promotion of active aging launched by the WHO about a decade ago. So, with the goal of improving the field of Educational Gerontology (Simões, 2006), it is important to elicit data to understand how the residential institutions for the elderly are actually responding to such a task, overcoming the sanitarian, 'assistentialist' and 'remedial' perspectives traditionally associated with this type of institutions, which have been seen as the last resource for families to deposit their elders when they were no longer able to respond to their needs.

\section{Methodology}

This study was developed in the scope of a larger research project supervised by the now retired Full Professor António Simões (e.g., Simões et al., 2006; 2010). It involved a bigger team of researchers (in which were included the authors of this chapter) from the now extinct research unit Centre of Psychopedagogy of the University of Coimbra, Portugal.

Sample

The sample of this study was composed by 146 institutionalized elders without cognitive impairments, all living in eight residential care institutions in the municipality of Coimbra, in the north central region of Portugal. The majority of the participants were females $(106 ; 72.6 \%)$ and males were the minority $(40 ; 27.4 \%)$. Their ages range from 59 to 100 years old, with an average of 81.25 ( 78.90 for men; 82.11 for women) and a standard deviation of 7.65. About their civil status, 14 (9.6\%) were married, 29 (19.9\%) were single, 93 (63.7\%) were widowed, 8(5.5\%) were 
divorced and $2(1.4 \%)$ preferred not to answer. Concerning school level, $46(31.5 \%)$ were illiterate, 30 (20.5\%) attended school but did not obtain any formal qualifications, 39 (26.7\%) completed four years of schooling, and only 25 (17.1\%) had gone beyond compulsory school for their time, having more than four years of schooling. Six participants (4.1\%) did not answer this question.

Among the reasons for the entry into the residential home, we can find in these seniors answers like the emergence of physical diseases ( $41 ; 28.1 \%)$, loneliness $(51 ; 34.9 \%)$, the death of a relative $(17 ; 11.6 \%)$ and other motives related to the incapacity of the family to take care of them $(37 ; 25.4 \%)$. When asked about their freedom of decision concerning the institutionalization process, 98 elders (67.1\%) said that they were in the institution by their own choice, 16 (11.0\%) agreed that they were previously reluctant to enter to the institution and $31(21.2 \%)$ mentioned that they were deceived by family members or relatives who did not tell them that they were going to the institution.

\section{Instrument}

In this study data were collected through a structured interview protocol composed by five distinct parts with low literacy demands, called Interview about the Quality of Life of Elderly People Living in Institutions. The first part of the protocol was conceived to obtain socio-demographic information about the respondents; the second part had questions related to the institutionalization process (type of institution; years of institutionalization, perception of autonomy in daily routines and rules, etc.); the third part was designed to evaluate subjective health; the fourth part involved questions related to social support networks; and the last part was dedicated to activities carried out by the institution and the level of participation of the elders.

The interview protocol was previously subjected to a pilot study with a small group of institutionalized elders, with whom a cognitive debriefing was done (George et al., 2013) in order to make the questions 
more accessible, after the identification of problematic words, unclear meanings and testing the adequacy of alternative answers in each section. The final version of the interview protocol is composed by sixty closed-ended questions.

\section{Procedure}

The participants in this study were independently contacted inside the institutions where they lived. After an explanation about the main goal of the research they were asked to answer the interview individually, with the interviewer ensuring the respect for all ethical principles that guide research with human subjects. Despite some lack of privacy in some institutions during data collection, the elderly were in general pleased to be asked about their life in institutions (Sardinha, 2008). Previously the research team obtained the consent of the Directive Board of the institutions to contact the residents and to spend some time with them collecting data.

\section{Results}

The data selected for presentation in this chapter are divided in two main parts, directly connected to the main objective of this particular study. So not all the sixty questions answered by the elders in the scope of the larger research project mentioned previously are explored here. The first part of data is related to the perceptions of the elderly about their autonomy and freedom of choice in the institutions where they live, considering aspects directly involved in their daily life as residents. The second part of data involves answers about learning, civic and other types of activities which they usually do inside and outside the residential institution, about their self-perception concerning their own abilities to learn and about the things they do to occupy free time and how satisfied they are about that. 


\section{Elders' perceptions about institutional life and their autonomy and freedom of choice}

As it is possible to see in Table 24, the majority of elders (53.8\%) are happy in general with their resident condition in an institution for the elderly and only $12.4 \%$ declared to be unhappy with institutionalization. One third (33.8\%) of the sample was not completely sure about the final answer and stated that they were more or less happy.

Table 24: Elders' general evaluation about their institutionalization

\begin{tabular}{lll}
\hline How do you feel about being institutionalized? $(\mathrm{n}=145)^{*}$ & $\mathrm{n}$ & $\%$ \\
\hline Happy & 78 & 53.8 \\
More or less happy & 49 & 33.8 \\
Unhappy & 18 & 12.4 \\
\hline Total *(1 missing value) & 145 & 100.0 \\
\hline
\end{tabular}

When asked about their satisfaction (Table 25) with general functioning of the institution, almost three quarters of the respondents $(72.6 \%)$ agreed that they were satisfied, $22.9 \%$ hesitated in giving a definitive answer to that question, and only 3.5\% expressed their dissatisfaction.

Table 25: Elders' satisfaction about the general functioning of the institution

\begin{tabular}{lll}
\hline Are you satisfied in general about the institution functioning? $(n=144) *$ & $\mathrm{n}$ & $\%$ \\
\hline Yes & 106 & 72.6 \\
More or less satisfied & 33 & 22.9 \\
No & 5 & 3.5 \\
\hline Total *(2 missing values) & 144 & 100 \\
\hline
\end{tabular}

Concerning the degree of freedom and control over their lives, data presented in Table 26 show clearly that the majority of the seniors answered that they had enough control over their personal issues and that they felt free to decide about their life. 
Table 26: Elders' perception about their degree of freedom and control over their life

\begin{tabular}{lll}
\hline $\begin{array}{l}\text { Do you feel that you have enough freedom and control over } \\
\text { your life? }(\mathrm{n}=144) *\end{array}$ & \multicolumn{2}{l}{$\%$} \\
\hline Yes & 97 & 67.4 \\
More or less & 25 & 17.4 \\
No & 22 & 15.2 \\
\hline Total *(2 missing values) & 144 & 100 \\
\hline
\end{tabular}

In order to help them to reflect about the decision to enter the residential institution, seniors were asked what their decision might be if they could go back in time and choose to go, or not to go, to the institution. Their answers shown in Table 27 revealed that $59.7 \%$ of them would take the same decision, $15.3 \%$ of them would hesitate and a quarter of them (25\%) would prefer an alternative solution to institutionalization.

Table 27: Elders' opinion about their decision to go to the institution if they could decide again

\begin{tabular}{lll}
\hline $\begin{array}{lll}\text { If you could decide again, would you choose to enter to the } \\
\text { residential care home? }(\mathrm{n}=144) *\end{array}$ & $\mathrm{n}$ & $\%$ \\
\hline Yes & 86 & 59.7 \\
Maybe & 22 & 15.3 \\
No & 36 & 25.0 \\
\hline Total *(2 missing values) & 144 & 100 \\
\hline
\end{tabular}

The evaluations of elders' satisfaction about their relations with the other seniors that live with them inside the institution are reported in Table 28. Most of them (60.4\%) confirmed that they are satisfied with their peer relations, 33.3\% declared to be more or less satisfied and only a minor percentage $(6.3 \%)$ revealed their dissatisfaction with this issue.

Table 28: Elders' perceptions about their relations with other seniors inside the institution

\begin{tabular}{lll}
\hline $\begin{array}{l}\text { How do you feel about your relations with other seniors that } \\
\text { live in this institution? }(\mathrm{n}=144) *\end{array}$ & $\mathrm{n}$ & $\%$ \\
\hline Satisfied & 87 & 60.4 \\
More or less satisfied & 48 & 33.3 \\
Unsatisfied & 09 & 6.3 \\
\hline Total *(2 missing values) & 144 & 100 \\
\hline
\end{tabular}


Elders' perceptions about their relations with their family visits and contacts are described in Table 29. Concerning this matter, $69.2 \%$ of the seniors interviewed said they were satisfied, $22.4 \%$ declared that they were more or less satisfied and only $8.4 \%$ expressed their disappointment with these relations.

Table 29: Elders' perceptions about their relations with their family

\begin{tabular}{lll}
\hline How do you feel about your relations with your family? $(\mathrm{n}=143)^{*}$ & $\mathrm{n}$ & $\%$ \\
\hline Satisfied & 99 & 69.2 \\
More or less satisfied & 32 & 22.4 \\
Unsatisfied & 12 & 8.4 \\
\hline Total *(3 missing values) & 143 & 100 \\
\hline
\end{tabular}

Other aspects of institutional life were approached in the interview, in order to ascertain old people's freedom of action and their participation in ordinary routines on a daily basis. Some of the answers can be found in Table 30 .

Table 30. Other answers about institutional life

\begin{tabular}{lll}
\hline $\begin{array}{l}\text { Separate questions about institutional life }(\mathrm{n}=144) * \\
\text { a) Did you choose your room? }\end{array}$ & $\begin{array}{l}\text { Yes } \\
(\mathrm{n} ; \%)\end{array}$ & $\begin{array}{l}\text { No } \\
(\mathrm{n} ; \%)\end{array}$ \\
$\begin{array}{l}\text { b) Are you alone in your room? } \\
\text { c) Did you choose the persons that sleep in your room? }\end{array}$ & $24(13.3)$ & $124(86.7)$ \\
$\begin{array}{l}\text { d) Did you know anyone institutionalized herebefore entering the } \\
\text { institution? }\end{array}$ & $18(13.1)$ & $119(83.2)$ \\
$\begin{array}{l}\text { e) Do you usually contact other seniors of the institution } \\
\text { just to talk or to ask for help? }\end{array}$ & $31(22.5)$ & $107(77.5)$ \\
\hline
\end{tabular}

*Missing values in these questions vary between 2 and 9. Questions b) and c) are mutually exclusive.

Despite their satisfaction with the situation of institutionalization and the regular functioning of the institutions previously highlighted, it is interesting to observe that the vast majority of the seniors participating in this study did not choose their rooms (86.7\%), were not alone in their accommodations (83.2\%), did not have the possibility to choose those persons who slept in the same home division with them (86.9\%), and 
did not know any person that had already been living there before they entered the residential home (77.5\%). Answers are not so extreme when they were asked whether they were in the habit of contacting other seniors of the institution just to talk (chat) or to ask for help. To this later question $65.2 \%$ of the interviewed responded positively and $34.8 \%$ said they did not do that.

\subsection{Elders' participation in learning and other types of activities}

Data collected with our seniors in this research showed that they are not regularly involved in learning or recreational activities that could improve their quality of life, whether they take place inside or outside the residential care institution. In Table 31 almost the totality of them (98.6) declared that they did not participate in learning or recreational activities inside the institution.

Table 31: Elders' participation in learning or recreational activities inside the institution

\begin{tabular}{lll}
\hline $\begin{array}{l}\text { Do you usually participate in any educational or recreational } \\
\text { Activities inside the institution? }(\mathrm{n}=142) *\end{array}$ & $\mathrm{n}$ & $\%$ \\
\hline Yes & 2 & 1.4 \\
No & 140 & 98.6 \\
\hline Total *(4 missing values) & 142 & 100 \\
\hline
\end{tabular}

In Table 32 it is possible to confirm that the participation of institutionalized elders of our sample in civic, volunteer or other types of activities that require coming out of the institution, the contact with other persons and the seniors' contributions to communitarian life is almost absent. In fact, $98.6 \%$ of them denied being involved in any such type of actions. 
Table 32: Elders' participation in civic or volunteering activities outside the institution

\begin{tabular}{lll}
\hline $\begin{array}{l}\text { Do you usually participate in any civic or volunteering activities } \\
\text { outside the institution? ( } \mathrm{n}=142)^{*}\end{array}$ & $\mathrm{n}$ & $\%$ \\
\hline Yes & 2 & 1.4 \\
No & 141 & 98.6 \\
\hline Total *(3 missing values) & 143 & 100 \\
\hline
\end{tabular}

It is interesting to analyze the data presented in Table 33, bearing in mind the answers shown in former tables. When asked to evaluate their ability to learn, 35.2\% declared they were satisfied with it, $51.1 \%$ said they were averagely satisfied and only $13.7 \%$ confirmed they were not satisfied (i.e., they were unable to learn).

Table 33: Elders' self-evaluation about their ability to learn

\begin{tabular}{lll}
\hline How do you feel about your ability to learn? $(\mathrm{n}=139) *$ & $\mathrm{n}$ & $\%$ \\
\hline Satisfied & 49 & 35.2 \\
More or less satisfied & 71 & 51.1 \\
Unsatisfied & 19 & 13.7 \\
\hline Total *(7 missing values) & 143 & 100 \\
\hline
\end{tabular}

According to what was expected after the literature research and was mentioned in the introductory section of this chapter, in our sample we found a positive significant correlation between elders' self-perception of their health condition and their evaluation of their own abilities to learn $(\mathrm{r}=0.242 ; \mathrm{p}<0.01)$. This indicator of association between variables is shown in Table 34. Therefore, the better seniors evaluate their health conditions, the more able they tend to feel in facing the challenges of learning tasks.

Table 34: Correlation between elders' perceptions of their bealth condition and ability to learn

\begin{tabular}{ll}
\hline Variables $(\mathrm{n}=139)(7$ missing values $)$ & Self-perception about the ability to learn \\
\hline Self-evaluation of health condition & $\mathrm{r}=0.242^{* *}$ \\
\hline$* * \mathrm{p}<0.01$ &
\end{tabular}


Results shown in Table 35 counteract any hope about the effective promotion of significant activities in residential homes for the elderly, based on the previous answer reported in Table 34. A scrutiny of the activities which institutionalized elders who responded to our interview protocol used to do to occupy their free time was the basis for the presentation of Table 35 .

Table 35: Activities performed by the elders to occupy free time

\begin{tabular}{lll}
\hline How do you spend your time in the institution? $(\mathrm{n}=144) *$ & $\begin{array}{l}\text { Yes } \\
(\mathrm{n} ; \%)\end{array}$ & $\begin{array}{l}\text { No } \\
(\mathrm{n} ; \%)\end{array}$ \\
\hline a) Watching television & $69(47.9)$ & $75(52.1)$ \\
b) Talking with friend/colleagues & $48(33.6)$ & $95(66.4)$ \\
c) Performing a particular hobby & $46(32.4)$ & $96(67.6)$ \\
d) Reading newspapers and magazines & $26(18.2)$ & $117(81.8)$ \\
e) Going for a walk & $41(28.7)$ & $102(71.3)$ \\
f) Practicing sports & $13(9.0)$ & $131(91.0)$ \\
g) Doing nothing & $34(23.6)$ & $110(76.4)$ \\
\hline
\end{tabular}

*Missing values in these questions vary between 2 and 3 .

Among activities described by the seniors it is important to emphasize that the great percentages of them that do not have reading habits (81.8), do not usually go for a walk (71.3), do not have particular hobbies (67.6\%), do not fraternize with peers, do not practice any sport (91\%) and said they do nothing in their free time (23.6\%). Although the lack of reading habits could be explained by the low literacy rates of the sample, other answers may not be expected in relation to institutions that work to ensure a life with quality for their residents. Watching television tended to be indicated by half of the respondents $(47.9 \%)$ as a normal activity to occupy their free time.

Table 36: Elders' satisfaction about the things they do to occupy their free time

\begin{tabular}{lll}
\hline How do you feel in relation to the things you do to & $\mathrm{n}$ & $\%$ \\
occupy your free time (n=140)* & 85 & 61.6 \\
\hline Satisfied & 35 & 25.4 \\
More or less satisfied & 20 & 13.0 \\
Unsatisfied & 140 & 100 \\
\hline Total *(6 missing values)
\end{tabular}


When asked how they feel about having such limited alternatives for occupying their free time and to exercise their full capacities (Table 36), most of our seniors declared themselves satisfied (61.6\%) with the opportunities offered by the institution, $25.4 \%$ revealed some hesitation in communicating their satisfaction and only $13 \%$ asserted that they were definitively displeased with the issue under analysis.

\section{Discussion}

The entrance of an elderly into a residential care institution tends to constitute an important transition in the individuals' life because it generally implies his/her adaptation to a new lifestyle, with less autonomy in daily habits and the need to respect a set of rules that determine collective life inside the institutions. Such a change could also require the seniors to make some readjustments in their relations with relatives and friends and also accept the establishment of new routines. Undoubtedly, for this transition to succeed, old people should also be open to making new acquaintances and should be able to live with people who up until then had been strangers. These, of course, pose questions related to the respect of privacy, intimacy and dignity of old people, which constitute fundamentals rights of all persons, regardless of age, and should be carefully observed by the local and central authorities who supervise institutions for the elderly.

The promotion of an active aging of the institutionalized elders should include a concern for their participation in society by different means, beyond the response to their needs for safety and security. If this happens, seniors can feel useful to others and can exercise their full abilities, avoiding the tendency sometimes associated with the institutionalization process of a progressive withdrawal from external social life (Preti, 1991), as if there was a rupture with previous networks and an abrupt cancellation of previously performed social roles.

In accordance with other studies focusing on elders' perception about their institutionalization (e.g., Santana et al., 2012; Cunha, 2013), seniors 
from our sample said that in general they were satisfied with the institutional contexts where they live, with their relations with peers, and with the contact they had with their families. But this study helped us to elicit information that deserves a careful reflection when we are dedicated as professionals to the promotion of an active aging of the population.

Despite the fact that in our sample there was a positive correlation between elders' self-perceptions of their own health conditions (cf. Table 34) and their ability to learn, almost all of them did not participate (98.6\%; cf., Tables 31 and 32) in regular activities with educational or civic purposes. Surprisingly, more than a half of the respondents $(61.6 \%)$ declared they were satisfied with that state of affairs and only $13 \%$ said they were unsatisfied (cf. Table 36).

From our perspective, these data are even more worrying if we compare seniors' self-evaluations about their own ability to learn (cf. Table 33) and the apparent complacency which appears in their agreement with the fact that it is not problematic for them not to do activities that encourage them to act as full citizens and that may keep them cognitively and civically active. Given this scenario, there seems to be in these elderly a certain resignation to this new but monotonous lifestyle and some accommodation to an 'assistentialist' environment where they receive care and support for basic needs, but where they do not have the opportunity to engage in critical thinking or participate in the everyday world of sharing knowledge and contributing to collective life.

According to article no. 72 from the Constitution of the Portuguese Republic, older people have the right to economic security and living conditions and to a family and community life that respect personal autonomy, avoiding and overcoming isolation or social marginalization; also, article no. 25 of the Letter of Fundamental Rights of the European Union states that the Union recognizes and respects the right of old people to have a dignified and independent life and also recognizes their right to participate in social and cultural life (Perista \& Perista, 2012). Elders' participation in learning, recreational, civic and spiritual activities, among others, has positive impacts on cognitive functioning and in their self-evaluation of health, well-being and quality of life (e.g., Simões, 
2006; Simões et al., 2010; Oliveira et al., 2011). But the existence of such opportunities for participation inside the residential institutions should be regulated beyond this knowledge and the aforementioned legal norms - and its absence should be legally penalized - by the official entities.

As it is possible to read in the Manual of Good Practices: a guide for residential care for older people - For leaders, professionals, residents and family (GCPAS/CID, 2005) ${ }^{55}$, published by Portuguese Institute of Social Security, with European financial support:

older people, when they are in situations that call for support, need quality responses. These responses should be developed with the perspective of the recognition of the right of elderly persons to full citizenship, equal opportunities, and participation in economic, social and cultural development. They also involve the access to necessary care, welfare and quality of life (p. 6).

Despite the small size of the sample, data obtained in this study showed that there is a long way to go in order to effectively offer opportunities for participation to institutionalized elders, whether it involves experiences of learning and of personal development, or ordinary decisions related to their daily life as individuals and full citizens. In fact, there are no 'standard seniors' that fit the requirements of a residential care home for seniors. Nor are there 'model' residential care homes, because they are located in specific socio-cultural contexts, with different resources and surroundings, and their potential 'clients' vary a lot from one to another.

So, it is not enough to develop social policies for social protection of the elderly; supervision and monitoring is also imperative, considering that seniors are not a homogeneous group and there are specific factors like low literacy rates, the emergence of chronic diseases or the lack of social support (outside and inside the institution) that could transform aging

55 Available in (accessed October, 21, 2013):

http://www4.seg-social.pt/documents/10152/13328/acolhimento_residencial_pessoas_mais_velhas 
into a very different process from one individual to another. In addition, there are more and more healthier and better educated elderly people, with better economic resources and who are perhaps more demanding (Simões, 2006) about their higher order needs (e.g., self-concept, self-determination, self-actualization), who live longer than in the past and who pose new challenges for society and for their caregivers.

Further research is needed in Educational Gerontology and other scientific fields to clarify which best practices can be developed in institutional contexts where seniors live, in order to promote their active aging and to ensure as much as possible the quality of their existence in the last years of their life. But, official entities that supervise residential homes for the elderly should also be aware about what kind of participation institutions are actually requiring from their residents with the goals of detecting situations of inefficiency and to reward and to disseminate good examples.

\section{References}

AEEASG (2012). Ano Europeu do Envelhecimento Ativo e da Solidariedade entre Gerações. Programa de Acção, 2012 | Portugal. Lisboa: Governo de Portugal.

Almeida, C. I. F. M. (2013). Sociedade "4-2-1". Impacto das politicas de envelhecimento ativo promovidas pela Câmara Municipal de Aveiro junto da população idosa, não institucionalizada, do concelho. Dissertação de Mestrado em Educação e Formação de Adultos e Intervenção Comunitária (não publicada). Coimbra: FPCEUC.

Baltes, P. B., \& Baltes, M. M. (1990). Psychological perspectives on successful aging: The model of selective optimization with compensation. In P. B. Baltes \& M. M. Baltes (Eds.), Successful aging: Perspectives from the behavioral sciences (pp. 1-34). New York: Cambridge University Press.

Cunha, L. B. (2013). Idosos institucionalizados. Testemunhos de vivências e de expetativas. Trabalho não publicado para a obtenção do Grau de Licenciatura em Serviço Social. Porto: Universidade Fernando Pessoa.

George, M., Pinilla, R., Abboud, S., Shea, J., \& Rand, C. (2013). Innovative use of a standardized debriefing guide to assist in the development of a research questionnaire with low literacy demands. Applied Nursing Research, 26, 139-142.

GCPAS/CID (2005). Manual de Boas Práticas. Um Guia para o acolhimento residencial de pessoas mais velhas. Para dirigentes, profissionais, residentes e famílias. Lisboa: Instituto da Segurança Social, I. P.

Jacob, L., \& Fernandes, H. (Coord.).(2011). Ideias para um envelhecimento activo. Almeirim: RUTIS. 
Kane, R. A. (2003). Definition, measurement, and correlates of quality of life in nursing homes: Toward a reasonable practice, research, and policy agenda. The Gerontologist, 43, 28-36.

Kelly, J. (1996). Activities. In J. E. Birren (Ed.), Encyclopedia of Gerontology (pp. 37-49). San Diego: Academic Press.

Knowles, M. (1990). The adult learner: A neglected species ( $4^{\mathrm{a}}$ ed.). Houston: Gulf Publishing Company.

Lima, M. P. (2010). Envelhecimento(s): Estado da Arte. Coimbra: Imprensa da Universidade de Coimbra.

Martins, R. M. L. (2010). Os idosos e as actividades de lazer. Millenium. Revista do IPV, 38, 243-251.

MIIPPA (2002). Political Declaration and Madrid International Plan of Action on Aging. New York: United Nations.

Oliveira, A. L., Vieira, C., Lima, M. P., Nogueira, S., Alcoforado, L., Ferreira, J. A., \& Zarifis, G. (2011). Developing instruments to improve learning and development of disadvantage seniors in Europe: The paladin project. In Pixel (Ed.), Conference proceedings of the International Conference The Future of Education (vol. 1, pp. 268-274). Florence: Simonelli Editore.

Perista, H. \& Perista, P. (2012). Género e envelhecimento. Planear o futuro começa agora! Estudo de diagnóstico. Lisboa: CIG.

Phellas, C. (2013). Quality of life and older people: An empirical study amongst older Cypriots. In C. Phellas (Ed.), Aging in european societies: Healthy aging in Europe (pp. 221-236). London: Springer.

Pretti, D. (1991). A linguagem dos idosos. São Paulo: Contexto.

Santana, I. O., Coutinho, M. P., Ramos, N., Santos, D. S., Lemos, G. L., \& Silva, P. B. (2012). Mulher idosa: Vivências do processo de institucionalização. ex aequo, 26, 71-85.

Sardinha, M. L. M. (2008). Qualidade de vida em idosos institucionalizados. Dissertação de Mestrado em Psicologia, área de Psicologia do Desenvolvimento (não publicada). Coimbra: FPCEUC.

Simões, A. (1990). Alguns mitos respeitantes ao idoso. Revista Portuguesa de pedagogia, XXIV, 109-121.

Simões, A. (1991). Aspectos do desenvolvimento cognitivo do idoso. Revista Portuguesa de Pedagogia, XXV(2), 177-185.

Simões, A. (1999). A educação dos idosos: Uma tarefa prioritária. Revista Portuguesa de Educação, 12(2), 7-27.

Simões, A. (2002). Um novo olhar sobre os idosos. Revista Portuguesa de Pedagogia, $36(1 / 2 / 3), 559-569$.

Simões, A. (2006). A nova velhice: Um novo público a educar. Porto: Ambar.

Simões, A., Lima, M. P., Vieira, C. M. C., Ferreira, J. A., Oliveira, A. L., Alcoforado, L., Neto, F. F. M., Ruiz, F., Cardoso, A. P., Felizardo, S., \& Sousa, L. N. (2006). Promover o bemestar dos idosos: Um estudo experimental. Psychologica, 42, 115-131

Simões, A., Oliveira, A. L., Lima, M. P., Vieira, C. M. C., \& Nogueira, S. M. (2010). O MLQ: Um instrumento para avaliar o sentido da vida. Psicologia, Educação e Cultura, XIV(2), 247-261. 